\title{
KESINAMBUNGAN DAN PERUBAHAN TRADISI SALAF DALAM SISTEM PENDIDIKAN PONDOK PESANTREN LIRBOYO KEDIRI
}

\author{
Kadi \\ Institut Agama Islam Negeri Ponorogo, Indonesia \\ E-mail: kadiabuzakaria@gmail.com
}

\begin{abstract}
This article answers the problem of continuity and change of salaf tradition in the educational system of Pondok Pesantren Lirboyo Kediri. Using system theory along with historical, sociological, anthropological and phenomenologycal appraoch, this article reveals some important points. First, the salaf tradition of pesantren undergoes substantial continuity, where knowledge structure of pesantren are conserved in learning of religious sciences originated from classical books, and partial change, where changes occur in the aspect of learning method, curriculum development, and teachers from outside pesantren. Second, there are internal and external factors that drive continuity and change in salaf tradition in the educational system of Pesantren Lirboyo. The internal factor is the attitude and thought of kiai as the servant of ummah (khadim al-ummah) and the objective condition of santri. While the external factor occurs because the development of the system of public education and the development of science and technology.
\end{abstract}

Keywords: Continuity and change; salaf tradition; substantial continuity; partial change.

\section{Pendahuluan}

Dinamika pondok pesantren saat ini menunjukkan fenomena menarik untuk dicermati. Lembaga pendidikan Islam tertua di Indonesia ini sedang mengalami semacam "krisis identitas" ketika berhadapan dengan arus perubahan dunia global yang sangat cepat. Di satu sisi, pondok pesantren ingin mempertahankan tradisi salaf sebagai identitas diri yang melekat sejak awal keberadaannya. Namun di sisi lain, perubahan sosial menuntut pondok pesantren untuk beradaptasi dan melakukan perubahan-perubahan terkait dengan cara pandang dan tradisi yang dianutnya. 
Karel A. Steenbrink mengungkapkan bahwa jika dilihat dari asalusulnya, tradisi pendidikan di pesantren memiliki kemiripan dengan tradisi Hindu mengingat seluruh pendidikannya bersifat agamis dengan beberapa ciri, di antaranya: guru tidak mendapat gaji, penghormatan yang besar terhadap guru (kiai), dan letak berdirinya pesantren yang jauh di luar kota. ${ }^{1}$ Kesimpulan seperti ini disepakati para ilmuwan seperti Nurcholish Madjid. ${ }^{2}$ Steenbrink juga sependapat jika pesantren dianggap sebagai bentuk kesinambungan dari sistem pendidikan zäwiyah atau khanaqah yang merupakan sistem pendidikan sufi di Timur Tengah. Hal ini jika dilihat dari pola pengajaran yang dimulai dengan bahasa Arab dan kental dengan ajaran sufistik. ${ }^{3}$

Tesis yang diungkapkan oleh Steenbrink perlu ditinjau ulang dalam konteks kekinian, mengingat adanya dinamika dalam sistem pendidikan pesantren dari waktu ke waktu. Dalam beberapa kasus, pesantren tidak lagi hanya fokus pada pendidikan agama, tetapi juga membuka diri bagi tumbuh kembangnya pendidikan umum atau perpaduan antara keduanya (pendidikan agama dan pendidikan umum). ${ }^{4}$

Pondok Pesantren Lirboyo adalah salah satu contoh pesantren yang memilih model ini. Selain fokus pada pendidikan agama melalui Madrasah Hidayatul Mubtadi'ien (untuk santri putra) dan Madrasah Hidayatul Mubtadi'at (untuk santri putri), pesantren ini juga memiliki lembaga pendidikan formal seperti Madrasah Tsanawiyah (MTs) dan Madrasah Aliyah (MA) Al-Mahrusiyah dan juga lembaga pendidikan umum seperti Sekolah Dasar (SD), Sekolah Menengah Pertama

\footnotetext{
${ }^{1}$ Lihat Karel A. Steenbrink, Pesantren, Madrasah, Sekolab: Pendidikan Islam dalam Kurun Modern (Jakarta: LP3ES, 1994), 20-21.

2 Dalam pandangan Madjid, pesantren tidak hanya mengemban nilai dan mengandung nuansa keislaman, tetapi juga menjaga nuansa keaslian (indigenous) Indonesia karena lembaga sejenis telah berdiri sejak masa Hindu-Buddha, sedangkan pesantren tinggal meneruskan dan mengislamkan saja. Lihat Nurcholish Madjid, "Merumuskan Kembali Tujuan Pendidikan Pesantren", dalam M. Dawam Rahardjo (ed.), Pergulatan Dunia Pesantren, Membangun dari Bawah (Jakarta: P3M, 1985), 3.

${ }^{3}$ Ibid., 22.

${ }^{4}$ Sanggahan terhadap tesis Steenbrink telah diajukan oleh Martin van Bruinessen yang mengatakan bahwa anggapan ini tidak didukung dengan bukti-bukti yang kuat dan ada alasan-alasan kuat untuk mempercayai bahwa corak pesantren yang ada pada abad sembilan belas tidak dapat ditemukan sebelum abad delapan belas. Lihat Martin van Bruinessen, NU, Tradisi, Relasi-relasi Kuasa: Pencarian Wacana Baru, terj. Farid Wajidi (Yogyakarta: LKiS, 2004), 15.
} 
(SMP), dan Sekolah Menengah Atas (SMA) ar-Risalah, juga menaungi sebuah perguruan tinggi yaitu Institut Agama Islam Tribakti (IAIT). ${ }^{5}$ Dalam kasus lain, walaupun Pondok Pesantren Lirboyo tidak membuka jalur pendidikan umum akan tetapi para lulusannya bisa melanjutkan ke lembaga pendidikan umum dengan modal ijasah mu'ädalah. ${ }^{6}$

Konsekuensi logis dari kondisi semacam itu adalah adanya pergeseran ciri-ciri tradisi dalam sistem pendidikan pesantren. Dengan mendirikan sekolah-sekolah umum atau madrasah, maka guru-guru yang ada di pesantren juga mulai mendapat penghargaan berupa gaji. Tidak jarang, sistem pembayaran gaji bagi guru-guru yang ada di pesantren dikembangkan mengikuti model penggajian yang ada di lembaga-lembaga pendidikan di luar pesantren. Tidak jarang pula, karena kebutuhan pengembangan lembaga pendidikannya, pesantren merambah daerah-daerah yang ada di sekitar perkotaan. Dengan demikian, pesantren saat ini tidak hanya menjadi lembaga pendidikan yang letaknya jauh di luar kota dengan akses yang terbatas, tetapi juga berada di pinggiran-pinggiran kota atau bahkan di tengah-tengah kota. Di antara ciri-ciri tradisi pesantren yang disebutkan Steenbrink, hanya penghormatan yang besar terhadap kiai yang tidak terlalu mengalami pergeseran.

${ }^{5}$ Lihat penelitian yang telah dilakukan oleh Ali Anwar, Pembaharuan Pendidikan di Pesanten Lirboyo Kediri (Yogyakarta: Pustaka Pelajar, 2011).

${ }^{6}$ Ada beberapa pesantren yang memilih model seperti ini. Pada tahun 2007, ada 32 pesantren yang sudah berstatus mu'ädalah. Dari 32 pesantren yang berstatus mu'ädalah tersebut, dari 300 guru, 294 diantaranya mendapat sertifikasi dan berhak memperoleh tunjangan profesi dari pemerintah. Diantara 32 pesantren yang berstatus mu'ädalah tersebut diantaranya adalah Pesantren Sidogiri Pasuruan, Pesantren Mbah Hamid Pasuruan, Pesantren Pabelan Magelang, Pesantren Darussalam Garut, dan Pesantren Darul Rahman Jakarta. Lihat Asrori S. Karni, Etos Studi Kaum Santri: Wajah Baru Pendidikan Islam (Bandung: Mizan Media Utama, 2009), 188-220.

7 Salah satu faktor tidak bergesernya penghormatan kepada kiai adalah peran yang dimainkan kiai dalam konteks kehidupan sosial. Menarik untuk dibaca tentang peran kiai hasil penelitian Geertz dan Horikoshi. Geertz menempatkan kiai sebagai makelar budaya (cultural broker) yang menyaring arus informasi yang masuk ke lingkungan kaum santri, menularkan apa yang dianggap berguna dan membuang apa yang dianggap merusak bagi mereka. Ketika arus informasi masuk begitu deras dan tidak mampu lagi disaring, maka kiai akan kehilangan perannya dalam perubahan sosial. Sementara Horikoshi memberikan antitesa yang menyimpulkan bahwa kiai adalah sosok yang berperan aktif dalam perubahan sosial. Kiai tidak melakukan penyaringan informasi, melainkan menawarkan agenda perubahan yang dianggap 
Mempertahankan tradisi atau mengikuti perubahan zaman yang berlaku di dunia pesantren banyak ditentukan oleh faktor kiai. ${ }^{8}$ Dalam hal ini kiai merupakan sosok pemimpin Islam yang memiliki posisi strategis di tengah-tengah masyarakatnya. Kiai dipandang sebagai orang yang memiliki pengetahuan lebih (terdidik) dan menduduki strata sosial yang cukup tinggi (elit). Sebagai elit-terdidik, kiai kemudian menjadi tokoh sentral yang mempengaruhi pengetahuan agama masyarakat yang disebarkan melalui lembaga pendidikan yang disebut pesantren. ${ }^{9}$ Kiai membentuk sebuah sistem sosial melalui sistem kekerabatan. Ada beberapa landasan yang menjadi pondasi terbentuknya sistem kekerabatan yang dibangun oleh kiai, di antaranya; hubungan kekerabatan genealogi sosial kiai, jaringan aliansi perkawinan, hubungan genealogi intelektual, dan hubungan antara guru dan murid yang terbentuk di dalam dan di luar pesantren. ${ }^{10}$ Sistem sosial yang dibentuk oleh kiai melalui jalur kekerabatan inilah yang kemudian menjadi tradisi pesantren. Dalam hal ini, tradisi pesantren harus dibaca sebagai; pertama, tradisi pesantren sebagai basis kultural dan kedua, tradisi pesantren sebagai mediator kepentingan antara kiai dan santri. ${ }^{11}$

Selain membangun sistem sosial yang menjadi tradisi pesantren, kiai juga terlibat aktif dalam terbentuknya tradisi keulamaan yang ada di pesantren. Tradisi keulamaan inilah yang mempengaruhi orientasi sistem pendidikan yang ada di pesantren. Dalam hal ini, Baso ${ }^{12}$

sesuai dengan kebutuhan nyata masyarakat yang dipimpinnya. Lihat Abdurrahman Wahid, "Benarkah Kyai Membawa Perubahan Sosial?: Sebuah Pengantar" dalam Hiroko Horikoshi, Kyai dan Perubahan Sosial (Jakarta: P3M, 1987), xvi-xvii.

${ }^{8}$ Dalam pandangan Langgulung misalnya, pribadi kiai dengan ilmu dan visi yang dimilikinya diduga merupakan faktor penting yang menentukan eksistensi pesantren sehingga tidak tergerus oleh perubahan zaman. Lihat Hasan Langgulung, Pendidikan Islam Menghadapi Abad ke-21 (Jakarta: Pustaka al-Husna, 1988), 75.

9 Penelitian tentang pemimpin-pemimpin Islam di Indonesia pernah dilakukan oleh Clifford Geertz pada tahun 1959 dan Horikoshi pada tahun 1976. Lihat Horikoshi, Kyai dan Perubahan Sosial (Jakarta: P3M, 1987). Lihat juga Clifford Geertz, "The Javanese Kijaji: The Changng Role of Cultural Broker", Comparative Studies in Society and History, Vol. 2, No 2 (1960).

${ }^{10}$ Saefuddin Zuhri, Guruku Orang-orang Pesantren (Bandung: PT. Al-Ma'arif, 1988), 58.

11 Terkait dengan pembacaan terhadap tradisi pesantren dan kaitannya dengan kiai sebagai aktor utama pembentukannya. Lihat Zamakhsyari Dhofier, Tradisi Pesantren: Studi tentang Pandangan Kyai (Jakarta: LP3ES, 2011), 60-78.

${ }^{12}$ Baca Ahmad Baso, Pesantren Studies, Jilid 2a (Jakarta: Pustaka Afid, 2013), 49-83. 
meyebutkan bahwa orientasi pendidikan pesantren bertumpu dan tidak akan lepas dari prinsip-prinsip pokok tradisi keulamaan yang di antaranya; Pertama, pendidikan merupakan sarana membentuk kemampuan bekerja dan berkarya untuk beramal saleh. ${ }^{13}$ Kedua, berguru merupakan sarana yang paling utama untuk membantu anak didik untuk memahami pengalaman manusia di dunia ini, untuk menguji dengan kritis berbagai kecenderungan dunia ini, dan untuk memahami karakter khusus bangsa. Ketiga, pendidikan pesantren adalah pendidikan seumur hidup yang mempertautkan tradisi keagamaan Aswaja dengan kehidupan kebangsaan.

Zamakhsyari Dhofier mengidentifikasi pondok pesantren Lirboyo sebagai salah satu pondok pesantren yang masih dikategorikan sebagai pesantren salaf. Walaupun telah mengalami pembaruan, pesantren ini tidak meninggalkan tradisi dan budaya asalnya. ${ }^{14}$ Terkait dengan persoalan menjaga tradisi, ada catatan penting dalam sejarah panjang pondok pesantren Lirboyo. Pada era awal tahun 1970-an, BPK P2L sebagai lembaga yang memegang kekuasaan tertinggi di pondok pesantren Lirboyo menolak usulan memasukkan mata pelajaran umum dalam kurikulum Madrasah Hidayatul Mubtadi'ien. ${ }^{15}$

${ }^{13}$ Dalam tipologi pesantren menurut Nasir, pesantren ideal adalah pesantren yang memiliki bentuk sebagaimana pesantren modern hanya saja lembaga pendidikan yang ada lebih lengkap, terutama bidang keterampilan yang meliputi pertanian, teknik, perikanan, perbankan, dan benar-benar memperhatikan kualitasnya dengan tidak menggeser ciri khusus kepesantrenannya yang masih relevan dengan kebutuhan masyarakat/perkembangan zaman. Ridwan Nasir mentipologikan pesantren menjadi lima: pesantren salaf/klasik, pesantren semi berkembang, pesantren berkembang, pesantren khalaf/modern, dan pesantren ideal. Lihat Ridwan Nasir, Mencari Tipologi Format Pendidikan Ideal: Pondok Pesantren di Tengah Arus Perubahan (Yogyakarta: Pustaka Pelajar, 2010), 87-88.

${ }^{14}$ Dhofier menyatakan bahwa Pesantren Lirboyo adalah benteng tradisi kader ulama dan pengawal tradisi pesantren terkuat di Indonesia pada saat ini. Langkah memadu modernitas merupakan perintah dan tuntutan tradisi. Langkah Pesantren Lirboyo merupakan langkah penting dalam rangka memaksimalkan mutu, isi dan sistem pendidikan dengan tetap memelihara paham Ablussunnab wal Jama'ah. Pesantren Lirboyo tidak mau membuang kerangka besar tradisi keilmuan Islam. Diselenggarakannya pendidikan SD, SMP, dan SMU merupakan perwujudan ajaran dan perintah wa al-akhdhu min jadid al-näfi' dalam bidang-bidang aktivitas sosial intelektual, cara hidup, kebiasaan-kebiasaan sosial, dan dalam aspirasi profesional. Lihat Dhofier, Tradisi Pesantren, 270-271. Sementara Ali Anwar mengungkapkan bahwa pembaruan pendidikan di Pesantren Lirboyo tidak hanya menjadikan pesantren ini survive dan berkembang tetapi juga dapat mempertahankan lembagalembaga pendidikan tradisionalnya. Lihat Anwar, Pembaharuan Pendidikan, 5.

${ }^{15}$ Ibid., 176. 
Penolakan ini bisa dimaknai sebagai proses identifikasi yang dilakukan oleh kalangan internal pesantren terhadap mata pelajaran umum yang dianggap sebagai "budaya luar" pesantren. Hal ini juga sejalan dengan tesis yang diungkapkan oleh Steenbrink bahwa tradisi pendidikan di pesantren memiliki kemiripan dengan tradisi Hindu mengingat seluruh pendidikannya bersifat agama. ${ }^{16}$

Namun demikian, di era yang sama di Pesantren Lirboyo dibentuk lembaga pendidikan Ar-Rabithah yang mengajarkan mata pelajaran umum seperti bahasa Inggris, ilmu psikologi, ilmu pendidikan, metode dakwah, ilmu hukum pidana dan perdata, ilmu kemasyarakatan, manajemen, dan administrasi. Lembaga pendidikan ini lahir dibidani oleh Kiai M. Anwar Manshur dan diresmikan oleh KH. Mahrus Aly selaku Pengasuh Pondok Pesantren Lirboyo sekaligus Ketua BPK P2L. ${ }^{17}$

Berangkat dari penjelasan di atas diketahui bahwa terjadi dinamika dalam hal pemaknaan terhadap tradisi salaf di Pondok Pesantren Lirboyo. Jika pendidikan yang bersifat agama pada awalnya diidentifikasi sebagai salah satu tradisi yang harus dipertahankan sebagai identitas pesantren salaf, pandangan semacam ini mungkin saja berubah seiring dengan realitas pondok pesantren Lirboyo saat ini. Perubahan yang terjadi bisa saja merupakan kesinambungan (continuity) $^{18}$ dari kondisi awal yang melatarbelakanginya atau bisa juga perubahan tersebut menciptakan kondisi baru yang "terlepas" dari keadaan sebelumnya (change). Dengan demikian maka fenomena yang terjadi di pesantren Lirboyo menjadi menarik untuk diteliti.

Artikel ini ingin mengurai kembali dinamika di Pondok Pesantren Lirboyo Kediri dengan menghindari kelemahan yang dimiliki oleh penelitian sebelumnya yaitu berupa celah teoretis dan celah metodologis. Untuk kepentingan tersebut, maka peneliti akan mengkaji dinamika yang terjadi di Pondok Pesantren Lirboyo Kediri dengan semua unit yang ada di dalamnya sehingga menghasilkan sebuah kesimpulan yang representatif yang mewakili kondisi objek

\footnotetext{
16 Steenbrink, Pesantren, 20-21.

17 Tim Penyusun, Pesanten Lirboyo, 176-177.

${ }^{18}$ Kata continuity selalu dirangkai dengan kata culture yang mengandung pengertian kesinambungan budaya dengan merata atau kesinambungan hidup atau budaya warga tertentu. Sementara kata change secara umum dapat diartikan sebagai peristiwa yang berhubungan dengan perubahan posisi unsur suatu sistem, hingga terjadi perubahan pada struktur sistem tersebut. Lihat G. Kartasapoetra dan Hartini, Kamus Sosiologi dan Kependudukan (Jakarta: Bumi Aksara, 1992), 76.
} 
penelitian secara menyeluruh. Lembaga-lembaga pendidikan yang ada di Pondok Pesantren Lirboyo Kediri akan dipandang sebagai satu kesatuan utuh dengan mengasumsikan bahwa semua dinamika yang terjadi di dalamnya bisa berupa kesinambungan (continuity) atau perubahan (change).

\section{Gambaran Umum Pondok Pesantren Lirboyo}

Lahirnya Pondok Pesantren Lirboyo merupakan bagian dari sebuah skenario besar yang dirancang oleh Kiai Sholeh Banjarmlati dalam mengemban misi dakwahnya menyebarkan agama Islam di wilayah Kediri. Kiai Sholeh juga banyak membangun masjid di berbagai wilayah Kediri dengan menggunakan kekuatan finansial yang dimilikinya. ${ }^{19}$ Upaya lain yang dilakukan Kiai Sholeh adalah dengan menyebar putra dan menantunya untuk mendirikan pondok pesantren di berbagai wilayah sekitar Kediri. Putri keenamnya (Nyai Khadijah/Dlomroh) dinikahkan dengan Kiai Abdul Karim (Kiai Manab) dan diperintahkan mendirikan pondok pesantren di Desa Lirboyo yang berjarak kurang lebih tiga kilometer sebelah Barat Laut Banjarmlati. ${ }^{20}$

Pada awalnya tradisi keilmuan yang dikembangkan oleh Kiai Manab adalah dengan mentransmisikan ilmu melalui sistem

19 Lihat Tim Penyusun, Pesanten Lirboyo, 13. Menurut Azra, keberadaan para pendakwah yang berprofesi sebagai saudagar yang kaya raya merupakan salah satu faktor penting proses Islamisasi di Nusantara. Islamisasi di Nusantara menurut Azra didukung oleh beberapa faktor, di antaranya: 1) Portabilitas sistem keimanan Islam yang siap pakai dan berlaku di mana pun sehingga sesuai bagi para pemeluk yang dinamis. 2) Asosiasi Islam dengan kekayaan. 3) Introduksi kebudayaan-peradaban literasi yang relatif universal. Lihat Azyumardi Azra, Renaisans Islam Asia Tenggara: Sejarah Wacana dan Kekuasaan (Bandung: Remaja Rosdakarya, 1999), 21-23.

20 Putri pertamanya dinikahkan dengan Kiai Ma'ruf dan mendirikan pondok pesantren Kedunglo berjarak sekitar satu kilometer ke arah utara dari Banjarmlati. Putri kedua dinikahkan dengan Kiai Fadhil dan mendirikan pondok pesantren Bathokan Desa Pethok sebelah Barat Daya Banjarmlati. Putri ketiga dinikahkan dengan Kiai Dahlan dan mendirikan pondok pesantren di Desa Jampes utara Banjarmlati. Putra keempatnya diperintahkan berdakwah di Desa Bandar Kidul yang bersebelahan dengan Desa Banjarmlati. Putri kelimanya dinikahkan dengan Kiai Manshur dan mendirikan pondok pesantren di Kalipucung Blitar. Putra kedelapan diperintahkan untuk membantu Kiai Abdul Karim membesarkan Pondok Pesantren Lirboyo. Putra kesembilan diperintahkan mendirikan pondok pesantren di Desa Cangkring Kecamatan Gurah Kediri arah Timur Laut dari Banjarmlati. Putra kesepuluh dan kesebelas ditugaskan menetap di Banjarmlati menemani Kiai Sholeh. Tim Penyusun, Pesanten Lirboyo, 13-14. 
pembelajaran sorogan dan bandongan. Cara seperti ini adalah cara lazim yang biasa digunakan oleh pondok-pondok pesantren salaf pada umumnya. ${ }^{21}$ Kiai menjadi patron bagi para santrinya karena otoritas keilmuan yang dimilikinya. ${ }^{22}$ Tahun 1925 menjadi catatan penting dalam sejarah perkembangan Pondok Pesantren Lirboyo dengan diadopsinya sistem klasikal dalam sistem pembelajaran di pondok tersebut. Berdirinya Madrasah Hidayatul Mubtadi'ien (MHM) menandai pergeseran terkait sistem pembelajaran di pondok Lirboyo. Namun demikian, sistem pembelajaran lama yang menggunakan metode sorogan dan bandongan tidak serta merta dihilangkan.

Setelah ditinggakan oleh pendirinya yaitu Kiai Manab yang wafat pada tahun 1954, ada semacam pergeseran model kepemimpinan di Pondok Pesantren Lirboyo dari semula kepemimpinan tunggal (Kiai Manab) menuju pada model kepemimpinan kolektif kolegial (Kiai Marzuki Dahlan dan Kiai Mahrus Aly). Kiai Mahrus Aly kemudian membentuk Badan Pembina Kesejahteraan Pondok Pesantren Lirboyo (BPK P2L) sebagai institusi tertinggi yang menaungi pondok pesantren dan lembaga-lembaga atau badan-badan yang berada di bawahnya. ${ }^{23}$

Pada tahun 1985 M. Kiai Mahrus Aly wafat, kepemimpinan Pondok Pesantren Lirboyo beralih ke generasi kedua. Kiai Ahmad Idris Marzuki (putra dari Kiai Marzuki Dahlan) didaulat sebagai pengasuh pondok sekaligus menjadi ketua Badan Pembina Kesejahteraan Pondok Pesantren Lirboyo (BPK P2L), sementara

${ }^{21}$ Dalam kurun waktu satu bulan Kiai Manab mampu membacakan 12 judul kitab dari berbagai disiplin ilmu. Dari sekian banyak kitab yang dibaca adalah kitab Qawäid, Naḥw, dan Saraf yang dibacakan mulai pagi hingga masuk waktu salat Ashar dengan diselingi istirahat salat Zuhur. Setelah salat Asar, ia membacakan kitab Tafsì al-Jalälayn. Ibid., 171-172.

22 Pada saat menimba ilmu di Syaikhona Kholil di Bangkalan, Kiai Manab berteman dengan Kiai Hasyim Asy'ari (Pendiri organisasi NU). Pulang dari Bangkalan, Kiai Manab dibekali dua kitab oleh gurunya yaitu kitab Ibn 'Aqül (sebuah kitab sharḥ dari Alfìyah b. Mälike) dan kitab Minhäj al-Qawìm (kitab tasawuf karya Abū Hāmid alGhazālī). Oleh karenanya, ilmu yang dikembangkannya ketika mendirikan pondok pesantren Lirboyo lebih didominasi oleh ilmu bahasa Arab (Naḥw dan Șaraf), serta ilmu tasawuf. Sampai saat ini pondok pesantren Lirboyo dominan dengan pembelajaran ilmu bahasa Arab, tasawuf dan fiqh. Lihat Tim Penyusun, Pesanten Lirboyo, 27-28.

${ }^{23}$ Lembaga ini dibentuk pada tanggal 15 November 1966 atas inisiatif Kiai Mahrus yang khawatir terjadi konflik internal di dalam tubuh Pondok Pesantren Lirboyo setelah ditinggal oleh para pendahulu (Kiai Sepuh). Lihat Tim Penyusun, Pesanten Lirboyo, 88. 
wakilnya dijabat oleh Kiai Abdul Aziz Manshur (putra dari Kiai Manshur Anwar). Di tangan generasi kedua ini, ${ }^{24}$ mulai bermunculan pondok-pondok unit dan pondok cabang (seperti pondok unit HM, HM Al-Mahrusiyah, Pondok Pesantren Putri Hidayatul Mubtadi'aat, Pondok Pesantren Haji Ya'qub, Pondok Pesantren Putri Tahfidz alQur'ān, dan lain sebagainya). Di samping itu, berkembang pula lembaga-lembaga pendidikan formal baik keagamaan (seperti MTs, MA, maupun perguruan tinggi Islam) maupun pendidikan formal umum (seperti SD, SMP, SMA, dan SMK). ${ }^{25}$ Ketika Kiai Idris Marzuki wafat pada tahun 2014, kepengasuhan pondok pesantren dijabat oleh Kiai Anwar Manshur dengan Kiai Abdullah Kafabihi Mahrus sebagai wakilnya.

\section{Genealogi Keilmuan Pondok Pesantren Lirboyo}

Seperti telah disinggung sebelumnya, kiai Manab/Kiai Abdul Karim (pendiri pondok pesantren Lirboyo) adalah murid dari Syaekhona Kholil Bangkalan Madura. Syaekhona Kholil Bangkalan Madura sendiri adalah murid dari Imam Nawawi al-Bantani. Ahmad Baso mengemukakan bahwa sanad Kiai Hasyim Asy'ari dan sejumlah ulama pendiri Nahdlatul Ulama terfokus pada mata rantai shaykh Nawawi al-Bantani dan pada silsilah Shaykh Sayid Ahmad Zaini Dahlan hingga ke Rasulullah. ${ }^{26}$

Kiai Manab dan generasi penerusnya memiliki kecenderungan utama terhadap empat jenis keilmuan yaitu: ilmu al-Qur'ān, gramatika bahasa Arab (Sarf/infleksi dan Nahw/sintaksis), fiqh, serta tasawuf. Salah satu indikasi dari kecenderungan tersebut dapat dilihat dari beberapa judul kitab yang di-gandrungi oleh Kiai Manab dan selalu diajarkan kepada keluarga dan santri-santrinya. Kebiasaan Kiai Manab dan para penerusnya mengajari putra-putrinya membaca al-Qur'ān serta kajian atas kitab Tafsir Jalälayn merupakan indikasi kuat adanya kecenderungan terhadap ilmu-ilmu al-Qur'ān. Kemudian kitab-kitab

\footnotetext{
${ }^{24}$ Walaupun jabatan pengasuh pondok pesantren dipegang oleh Kiai Ahmad Idris Marzuki, namun pada periode ini tugas kepengasuhan dilakukan secara kolektif bersama Kiai Maksum Jauhari (putra dari Kiai Jauhari), Kiai Imam Yahya Mahrus (putra dari Kiai Mahrus), dan Kiai Anwar Manshur (putra dari Kiai Manshur Anwar).

25 Penjelasan lebih detail terkait lembaga-lembaga tersebut beserta analisisnya akan di bahas pada bab berikutnya.

${ }^{26}$ Lihat Ahmad Baso, Islam Nusantara: Ijtihad Jenius \& Ijma' Ulama Indonesia, Vol. 1 (Tangerang Selatan: Pustaka Afid, 2017), 40.
} 
seperti Mukhtasar Jiddan (al-Ajjurümìyah), Alfìah b. Mälik, Jawhar alMaknūn, dan Mughni Labìb menjadi indikasi ketertarikan kiai Lirboyo terhadap disiplin ilmu gramatika bahasa Arab. Demikian pula dengan kitab-kitab seperti Fath al-Qarīb dan Fath al-Mu'n menjadi indikasi kuat atas kecenderungan terhadap disiplin ilmu fiqh. Sementara kitab Sullam al-Tawfíq dan Daläil al-Khayrät menjadi indikator atas kecenderungan terhadap disiplin ilmu tasawuf.

Transmisi ilmu pengetahuan dari kiai kepada santri di pondok pesantren Lirboyo terjadi melalui berbagai dimensi pembelajaran sebagai berikut: pertama, jika dilihat dari aspek interaksi edukatif antara kiai dan santri, transmisi ilmu pengetahuan di pondok pesantren Lirboyo terjadi melalui tiga jalur: a). Santri menerima ilmu pengetahuan langsung dari kiai; b). Santri menerima ilmu pengetahuan dari para ustaz (mustahiq) yang berperan sebagai wakil dari kiai; c). Santri memperoleh ilmu pengetahuan dari hasil interaksi mereka dengan teman-temannya sesama santri. Kedua, jika dilihat dari aspek waktu yang dibutuhkan untuk sebuah proses pembelajaran dan pemahaman terhadap satu bidang ilmu pengetahuan tertentu, maka transmisi ilmu pengetahuan terjadi melalui dua jalur, antara lain: a). Santri menerima ilmu pengetahuan melalui kegiatan belajar mengajar (KBM) terstruktur yang ada di Madrasah Diniyah maupun lembagalembaga pendidikan formal. Waktu yang dibutuhkan pada proses seperti ini bisa bertahun-tahun sesuai dengan ketentuan yang ada di dalam Madrasah Diniyah atau lembaga-lembaga pendidikan formal yang diikuti oleh santri; dan b). Santri menerima ilmu pengetahuan melalui jalur ngaji pasaran ataupun jalur ijazahan. Waktu yang dibutuhkan pada proses ini relatif lebih pendek.

Secara teoretis model pembelajaran melalui ijazaban dianggap tidak akan efektif digunakan sebagai sarana transfer of knowledge. Namun pemberian silsilah (sanad) pada proses ijazahan bisa dianggap memberikan dampak positif pada kondisi psikologis santri. Secara implisit kiai mengajarkan tentang penghargaan dan rasa hormat terhadap guru atau orang-orang yang telah berbagi pengetahuannya kepada orang lain (muridnya). Periwayatan seperti itu juga menaikkan posisi ilmu yang diwariskan pada tingkat yang sakral. Dapat disimpulkan bahwa ijazahan walaupun tidak efektif sebagai sarana transfer of knowledge, namun efektif digunakan sebagai sarana transfer of value. 


\section{Relasi Sosial Antar-Kiai Pondok Pesantren Lirboyo}

Secara umum struktur sosial kiai pondok pesantren Lirboyo terdiri dari kiai yang menjadi pengasuh atas keseluruhan santri dan kiai pengasuh pondok unit. Kemudian secara kelembagaan, struktur sosial lembaga-lembaga pendidikan di pondok pesantren terdiri dari pondok induk, pondok unit, dan pondok cabang. Pola kepengasuhan dapat dibagi menjadi dua fase: pertama, fase pertumbuhan yaitu periode kepemimpinan perorangan antara tahun 1910-1966; dan kedua, fase perkembangan yaitu periode kepemimpinan kolektif yang dimulai sejak dibentuknya BPK P2L pada tahun 1966.

Praktik keagamaan komunitas pondok pesantren Lirboyo sangat diwarnai oleh bangunan keilmuan yang dimilikinya. Sebagaimana telah dipaparkan sebelumnya, bahwa bangunan keilmuan di pondok pesantren Lirboyo disusun atas dasar kecenderungan yang kuat terhadap empat jenis bidang keilmuan yaitu; ilmu al-Qur'ān, gramatika bahasa Arab, figh, dan tasawuf. Kecenderungan tersebut akhirnya mempengaruhi perilaku keagamaan yang nampak dalam kehidupan mereka sehari-hari. Secara umum dapat dikatakan bahwa komunitas pondok pesantren Lirboyo mengidentifikasi dirinya sebagai penganut paham keagamaan Ahl al-Sunnah wa al-Jamā'ah. Dalam praktik peribadahannya, mereka lebih banyak mengikuti kaidah-kaidah fiqh mazhab al-Shāfíī.

Kitab kuning menjadi sumber inspirasi komunitas Pondok Pesantren Lirboyo dalam menyusun nilai-nilai yang dijadikan sebagai pedoman hidup sekaligus menjadi tempat untuk menemukan solusi atas problem yang dihadapi. Untuk memecahkan persoalan-persoalan keagamaan dan sosial kemasyarakatan, komunitas Pondok Pesantren Lirboyo menempuh mekasnisme musyawarah dengan merujuk kepada dalil-dalil hukum dan keagamaan yang tertuang di dalam kitab kuning. Mekanisme ini sering juga disebut sebagai forum bạ̣th al-masā'il.

Kiai Abdullah Kafabihi Mahrus ${ }^{27}$ mengungkapkan bahwa forum bạ̣th al-masāil difungsikan untuk beberapa kepentingan di antaranya:

a. Memonitor perkembangan zaman. Dalam hal ini pihak pondok pesantren melalui forum ini melakukan monitoring terhadap keadaan zaman yang terus berubah untuk kemudian dibahas dan dibicarakan dengan menggunakan sudut pandang kitab kuning.

b. Memecahkan persoalan-persoalan hukum, keagamaan, dan persoalan social kemasyarakatan. Seringkali pihak pondok

${ }^{27}$ Kiai Kafabihi Mahrus, Wawancara, Kediri 25 Januari 2017. 
pesantren menemukan sendiri atau diminta oleh pihak lain untuk memberikan solusi atas problem hokum, keagamaan, dan sosial kemasyarakatan. Forum baḥth al-masä̈il dipilih oleh Pondok Pesantren Lirboyo sebagai mekanisme terbaik merespon keadaan tersebut.

c. Sebagai filter yang menyaring berbagai dinamika sosial di luar pondok pesantren. Berbagai gagasan dan praktik pendidikan di luar pondok pesantren seringkali "menggoda" pondok pesantren untuk "ikut-ikutan" mengadopsi gagasan dan praktik pendidikan tersebut. Forum baḥth al-masäìl akan mengkaji secara mendalam berbagai gagasan tersebut dan memilih gagasan-gagasan yang dianggap cocok dengan model pendidikan di Pondok Pesantren Lirboyo.

Dengan melihat fakta di atas, maka dapat disimpulkan bahwa perilaku keagamaan komunitas masyarakat di Pondok Pesantren Lirboyo didasari oleh sebuah kerangka epistemik keislaman yang berpusat pada kitab kuning. Kitab-kitab klasik tersebut dijadikan rujukan utama dalam memahami agama Islam. Pemahaman terhadap agama Islam melalui kitab kuning inilah yang kemudian membentuk berbagai pola perilaku keagamaan kiai dan santri Pondok Pesantren Lirboyo.

Ada yang menarik jika mengamati eksistensi tarekat di dalam sistem kehidupan komunitas Pondok Pesantren Lirboyo. Tidak seperti pondok pesantren-pondok pesantren lain yang secara terbuka mendeklarasikan diri sebagai penganut ajaran tarekat tertentu, di Pondok Pesantren Lirboyo sulit untuk menemukan jejak dari tarekat tertentu yang menjadi mainstream yang dianut oleh sebagian besar anggota komunitas pesantren. Lebih sulit lagi jika muncul keinginan untuk memberi label tarekat tertentu sebagai bagian dari identitas Pondok Pesantren Lirboyo.

Eksistensi tarekat di Pondok Pesantren Lirboyo tidak ditemukan dalam bentuk institusi yang terlembagakan. Eksistensi tarekat ditemukan dalam bentuk ajaran (tasawuf) yang tetap dipertahankan secara turun temurun. Para Kiai Pondok Pesantren Lirboyo memegang teguh kebijakan Kiai Manab (pendiri) yang menyatakan bahwa tarekat di Pondok Pesantren Lirboyo adalah dalam bentuk alTa'lim wa al-Ta'allum (mengajar dan belajar).

Berbeda dengan pondok pesantren-pondok pesantren lain yang mendeklarasikan sebagai pusat tarekat tertentu yang terlembagakan, 
Pondok Pesantren Lirboyo tidak mengikatkan diri pada salah satu tarekat tertentu (Qādirīyah, Naqsabandīyah, Shādilīyah, dan lain sebagainya). Bagi komunitas Pondok Pesantren Lirboyo, belajar dan kemudian mengajar (jika sudah dianggap mampu) adalah ajaran tarekat yang harus diikuti dan dipertahankan sebagai bentuk kesetiaan terhadap pesan dan ajaran pendiri pondok pesantren ini. Tidak mengherankan jika para santri yang hendak meninggalkan Pondok Pesantren Lirboyo (entah karena sudah menyelesaikan studi atau karena sudah tidak meanjutkan ke jenjang yang lebih tinggi), mereka akan dibebani oleh kiainya kewajiban untuk ngadep dampar (mengajar) di tempat asalnya masing-masing sesuai dengan kemampuannya masing-masing. ${ }^{28}$

Dari paparan di atas, penulis berkesimpulan bahwa pada hakikatnya Pesantren Lirboyo memiliki kedekatan dengan tarekat. Hanya saja perlu digarisbawahi bahwa kedekatan itu tidak dalam bentuk keterikatan dan partisipasi aktif pada salah satu tarekat tertentu. Kedekatan Pesantren Lirboyo dengan tarekat lebih dalam bentuk kesetiaan terhadap ajaran tasawuf tertentu yang telah dijadikan garis kebijakan sejak berdirinya pondok pesantren ini. Perlu ditambahkan pula di sini bahwa kesetiaan terhadap ajaran Kiai Manab sebagaimana ditunjukkan oleh komunitas Pondok Pesantren Lirboyo mirip dengan model kesetiaan para pengikut tarekat terhadap murshidnya.

\section{Faktor yang Mempengaruhi Kesinambugan dan Perubahan Tradisi Salaf}

Ada pernyataan menarik dari Kiai Habibulloh Zaini sebagai salah seorang pengasuh Pondok Pesantren Lirboyo ketika memberikan pengantar pada sidang Badan Pembina Kesejahteraan Pondok Pesantren Lirboyo (BPK P2L) pada tanggal 28 Agustus 2016. Dalam kata pengantarnya, kiai yang menjabat sebagai sekertaris BPK P2L ini mengatakan,"Badan Pembina dalam mengambil keputusan sangatlah hati-hati dengan mengutamakan keselamatan umum pendidikan Pondok Pesantren Lirboyo dan mengambil garis kebijaksanaan yang pernah mengantarkan keberhasilan orang-orang terdahulu demi

\footnotetext{
${ }^{28}$ Kiai An'im Falahuddin Mahrus, Wawancara, Kediri 18 Januari 2017.
} 
keselamatan pendidikan dan pengajaran". ${ }^{29}$ Kemudian dia menyitir kalimat yang pernah dilontarkan oleh Imam Malik yang berbunyi:

$$
\text { لا يصلح امر هذه الامة الا بما صلح به اوائله }
$$

Tidaklah akan menjadi baik (maslahat) urusan umat ini kecuali dengan kebaikan yang telah dibuat oleh para pendahulunya.

Pernyataan di atas memberikan gambaran tentang sikap dan pemikiran kiai Pondok Pesantren Lirboyo tentang tindakan yang harus dilakukan dalam mengelola pondok pesantren. Dari pernyataan itu pula setidaknya dapat disimpulkan beberapa hal: pertama, ada kesadaran yang tertanam di dalam pikiran kiai Lirboyo bahwa capaian prestasi pesantren bidang pendidikan dan pengajaran serta menciptakan kader-kader penerus sejauh ini tidak bisa dilepaskan dati jerih payah generasi sebelumnya. Kedua, dengan mengasumsikan bahwa sikap dari Kiai Habibulloh Zaini ini adalah representasi dari sikap para pengasuh pondok pesantren yang tergabung dalam Badan Pembina Kesejahteraan Pondok Pesantren Lirboyo (BPK P2L), maka hal ini mencerminkan adanya sikap kehati-hatian dalam pengambilan keputusan strategis oleh Badan Pembina Kesejahteraan Pondok Pesantren Lirboyo (BPK P2L) yang merupakan lembaga pemangku kebijakan tertinggi. Sikap ini disebabkan oleh keinginan kuat untuk tidak menyalahi kebijaksanaan yang telah digariskan oleh para pendahulunya.

Gagasan yang bisa ditangkap dari ungkapan di atas adalah bahwa bagi para kiai, tatanan kehidupan yang telah dibentuk oleh para pendahulu memiliki arti penting bagi keberlangungan eksistensi Pondok Pesantren Lirboyo hari ini. Inovasi dan pengembangan pondok pesantren tidak boleh "merusak" apalagi "meniadakan" tatanan sosial yang sudah ada sebelumnya. Sikap seperti inilah yang mendominasi pemikiran kiai-kiai lain yang ada di Pondok Pesantren Lirboyo yang peneliti wawancarai seperti Kiai Abdullah Kafabihi, Kiai An'im Falachuddin Mahrus, dan lain-lain. ${ }^{30}$

\footnotetext{
${ }^{29}$ KH.A. Habibullah Zaini, "Kata Pengantar" dalam Tim Penyusun, Ketetapan Badan Pembina Kesejahteraan Pondok Pesantren Lirboyo Masa Khidmah: 1437-1438 H./20162017 M. (Kediri: t.tp., 2016), 3-4.

${ }^{30}$ Pernyataan di atas juga mempertegas posisi kiai yang memiliki posisi tertinggi dari hirarki kekuasaan intern di pesantren dan memiliki kedudukan ganda sebagai pengasuh dan sekaligus pemilik pesantren. Lihat Abdurrahman Wahid, "Pesantren sebagai Subkultur" dalam M. Dawam Rahardjo, Pesantren dan Pembaharuan (Jakarta: LP3ES, 1985), 43-46. Kiai merupakan sumber mutlak dari kekuasaan dan
} 
Pengalaman sehari-hari para kiai dan interaksi sosial mereka dengan dunia luar pesantren harus diakui memberi pengaruh yang cukup signifikan bagi lahirnya rumusan kebijakan yang mengakomodir "tradisi baru" pada lembaga tertinggi pondok pesantren ini. Namun sebagaimana tercermin dalam sambutan Kiai Habibullah Zaini di atas, para kiai ini juga "tidak merelakan" tradisi warisan para leluhurnya hilang begitu saja. Untuk menjembatani dua kondisi tersebut, seringkali sebuah keputusan lahir dari perdebatan-perdebatan antar anggota lembaga ini dan melibatkan doktrin-doktrin agama sebagai pijakan pengambilan keputusan. Doktrin agama yang dimaksud adalah sejumlah argumen agama yang tertuang dalam kitab kuning, sehingga forum musyawarah di lembaga ini memiliki kemiripan dengan forum bahth al-masä'il yang menjadi bagian integral tradisi pesantren. Dari sini juga dapat ditemukan bahwa selain pengetahuan dan pengalaman individu para kiai, forum baḅth al-masäil pondok pesantren juga menjadi sumber informasi yang ikut mempengaruhi kebijakankebijakan lembaga BPK P2L (Badan Pembina Kesejahteraan Pondok Pesantren Lirboyo).

Sebagaimana diungkapkan oleh Kiai Kafabihi, untuk menyeleksi hal-hal baru yang akan diadopsi atau ditolak oleh pesantren dilakukan melalui mekanisme bahth al-masäill. Mekanisme ini memastikan apakah sebuah "tradisi baru" tersebut bisa diterima atau tidak sebagai bagian dari pola kehidupan pesantren. Dalam hal ini, perlu ditambahkan catatan bahwa walaupun pada akhirnya, sebuah "tradisi baru" diterima sebagai bagian dari tadisi Pondok Pesantren Lirboyo, akan tetapi harus lolos uji dalam forum bạ̣th al-masäill. Itu artinya, pembahasan dengan menggunakan referensi-referensi yang merujuk kepada karyakarya klasik abad pertengahan menjadi tolok ukur utama bagi diterima atau ditolaknya sesuatu yang baru. Hasil dari forum bahth al-masāill ini-sebagaimana disampaikan Kiai Kafabihi-akan menjadi pertimbangan penting bagi para kiai untuk mengambil keputusan dalam rapat BPK P2L (Badan Pembina Kesejahteraan Pondok Pesantren Lirboyo). Yang ingin penulis katakan bahwa komunitas Pesantren Lirboyo menggunakan trdaisi salaf dalam bentuk kajian

kewenangan (power and authority) dalam kehidupan dan lingkungan pesantren. Lihat Dhofier, Tradisi Pesantren, 55. 
terhadap referensi-referensi salaf (forum bahth al-masäì) untuk mengambil langkah-langkah strategis pengembangan pendidikannya. ${ }^{31}$

Jika dirunut ke belakang, keterlibatan doktrin agama dalam sebuah kebijakan bukanlah persoalan yang baru di Pondok Pesantren Lirboyo. Hal semacam itu pernah terjadi pada zaman kepemimpinan Kiai Mahrus Aly dan Kiai Marzuki Dahlan. Misalnya kebijakan diperbolehkan atau tidaknya santri dan komunitas Pondok Pesantren Lirboyo memakai sarung yang terbuat dari kain sutera lahir dari perdebatan dua orang Kiai tersebut yang melibatkan doktrin agama. Kiai Marzuki Dahlan mengharamkan pemakaian sarung tersebut sebagaimana hukum fiqh yang ada di dalam kitab kuning. Sementara Kiai Mahrus Aly memperbolehkan dengan dalih tidak ada sarung yang seratus persen bahannya terbuat dari sutera sebagaimana yang dimaksud oleh penjelasan kitab kuning tersebut. Demikian pula yang terjadi ketika kebijakan pondok pesantren untuk melarang untuk menggunakan kopyah (penutup kepala) yang berwarna putih bagi santri yang belum menunaikan ibadah haji.

Berbagai kebijakan yang lahir dari pemikiran kiai sangat terkait dengan pola kehidupan santri. Sebuah kebijakan yang dikeluarkan oleh kiai akan menjadi norma yang harus ditaati oleh semua santri. Sebaliknya, seringkali kondisi objektif santri turut berkontrbusi bagi lahirnya kebijakan dan norma-norma yang dikeuarkan oleh kiai. Dapat dikatakan bahwa kiai dan santri secara bersama-sama membentuk sebuah pola hubungan sosial yang unik khas pesantren.

Pertumbuhan santri secara terus-menerus ini ternyata juga berpengaruh terhadap cara berpikir kiai dalam mengelola pendidikan yang ada di Lirboyo. Salah satunya adalah gagasan untuk memperkaya metode belajar. Kiai An'im mengungkapkan bahwa sistem klasikal atau sistem madrasi diterima masuk ke dalam sistem pendidikan

31 Kajian terhadap referensi-referensi salaf dalam forum baḅth al-masä'il dalam perspektif Abdurrahman Wahid merupakan prestasi sekaligus kekhasan pesantren dalam mengakrabi nilai-nilai universal kitab kuning. Lihat kembali Abdurrahman Wahid, Menggerakkan Tradisi: Esai-esai Pesantren (Yogyakarta: LKiS, 2010), 97-104. Selain itu, hal tersebut juga menimbulkan: 1) penghayatan mental spiritual keagamaan dan tafaqquh fi al-din. 2) pelestarian nilai-nilai keagamaan seperti kesederhanaan, keikhlasan, ukhwmwah, kebaktian, dan keswadayaan. 3) lebih condong pada pengutamaan social effect daripada civil effect. 4) melahirkan pemimpin, baik formal maupun nonformal yang berpengaruh bagi masyarakat di lingkungannya. 5) penyebarluasan dakwah Islam. Lihat Abdul Rachman Saleh, Pendidikan Agama dan Keagamaan: Visi, Misi, dan Aksi (Jakarta: Gemawindu Pancaperkasa, 2000), 225-226. 
pesantren Lirboyo dengan mempertimbangkan jumlah santri yang semakin banyak. Dalam kondisi seperti itu, tidak mungkin dibiarkan tetap mengaji dengan cara satu persatu menghadap kiai. Demikian pula dengan metode belajar. Dengan diterapkannya sistem madrasi, maka metode pembelajaran pun tidak terbatas hanya pada sorogan, bandongan, dan wetonan. Metode ceramah, diskusi, dan tanya jawab akhirnya diadopsi untuk melengkapi metode belajar yang telah ada.

Dengan demikian, maka harus diakui bahwa kondisi objektif santri juga turut berkontribusi bagi munculnya gagasan-gagasan "baru" di kalangan kiai. Ragam gagasan tersebut tidak hanya menyangkut manajemen pengelolaan sistem pendidikan di Pondok Pesantren Lirboyo, akan tetapi lebih dari itu juga bisa menyentuh persoalan-persoalan fundamental terkait dengan upaya pelestarian tradisi salaf di tengah arus perubahan zaman yang sulit untuk dielakkan.

\section{Relasi Tradisi Salaf dan Tradisi Lain}

Pintu pertama masuknya sistem pendidikan umum ke dalam kehidupan Pondok Pesantren Lirboyo diawali dengan gagasan Kiai Mahrus Aly untuk mendirikan perguruan tinggi Islam pada tahun 1965. Pada periode antara tahun 1975-1976 gagasan memadukan pendidikan agama dan pendidikan umum muncul kembali melalui lembaga pendidikan Ar-Rabithah yang digagas oleh Kiai Anwar Manshur yang tidak lain adalah menantu dari Kiai Mahrus Aly. Gagasan tersebut juga berpengaruh terhadap peristiwa didaftarkannya Tingkat Ibtida'iyyah Madrasah Hidatul Mubtadiien ke Depatemen Agama pada tahun 1978. Dampak dari peristiwa tersebut adalah pengakuan atas ijazah yang disetarakan dengan ijazah pendidikan formal sehingga dapat digunakan untuk melanjutkan pendidikan di lemaga pendidikan manapun (setingkat SLTP) di luar Pondok Pesantren Lirboyo.

Dampak yang lebih masif dari gagasan Kiai Mahrus Aly tersebut terlihat pada tahun 1988 ketika puteranya yang bernama Kiai Imam Yahya Mahrus mendirikan pondok unit HM Putera. Berdirinya pondok unit ini menandai berdirinya berbagai lembaga pendidikan formal baik yang bersifat keagamaan maupun umum. Di bawah naungan pondok unit yang sekarang disebut PP HM Al-Mahrusiyah ini hingga saat ini terdapat lembaga-lembaga pendidikan formal setingkat SLTP dan SLTA. Untuk tingkat SLTP pondok unit ini 
menaungi Madrasah Tsanawiyah al-Mahrusiyah, sementara untuk tingat SLTA pondok unit ini mengelola Madrasah Aliyah alMahrusiyah dan SMK Al-Mahrusiyah.

Gagasan untuk menerima pendidikan umum sebagai bagian dari sistem pendidikan di Pondok Pesantren Lirboyo juga diikuti oleh cucu dari Kiai Mahrus yang mendirikan pondok unit Ar-Risalah. Nyai Aina Ainun Mardliyah bersama suaminya Kiai Ma'ruf Zainuddin mendirikan Pondok Pesantren Salafiyah Terpadu Ar-Risalah (PPST Ar-Risalah) pada tahun 1995. Di pondok pesantren unit ini didirikan lembaga pendidikan formal non-keagamaan berupa SD, SMP, dan SMU Ar-Risalah. Pada tahun-tahun berikutnya, ada beberapa pondok unit yang mengambil kebijakan memperbolehkan santrinya untuk menempuh pendidikan formal (sekolah) di luar pondok pesantren. Pondok unit-pondok unit tersebut di antaranya adalah PPHY dan PPDS. $^{32}$

Fakta di lapangan menunjukkan bahwa sistem tradisi yang dimiliki oleh Pondok Pesantren Lirboyo tidak resisten terhadap perkembangan ilmu pengetahuan dan teknologi. Ada proses akomodasi yang dilakukan oleh komunitas pondok pesantren ini terhadap ilmu pengetahuan dan teknologi yang pada awalnya "bukan bagian" dari sistem tradisi mereka.

Beberapa bukti yang memperkuat pernyataan di atas perlu dipaparkan di sini beberapa ilmu pengetahuan dan teknologi yang diakomodir dan sebagian sudah menjadi bagian dari tradisi di Pondok Pesantren Lirboyo. Di antara ilmu pengetahuanyang diakomodir di antaranya: Ilmu Pendidikan, ${ }^{33}$ Manajemen Organisasi, ${ }^{34}$ Jurnalistik, dan Karya Tulis Ilmiah. ${ }^{35}$

\footnotetext{
32 Menurut Azra, ada dua cara yang ditempuh pesantren dalam merespons ekspansi sistem pendidikan umum, yaitu: 1) Merevisi kurikulum dengan memasukkan semakin banyak mata pelajaran umum atau bahkan keterampilan umum. 2) Membuka kelembagaan dan fasilitas-fasilitas pendidikannya bagi kepentingan pendidikan umum. Azyumardi Azra, Pendidikan Islam: Tradisi dan Modernisasi Menuju Milenium Baru (Jakarta: Logos, 1999), 102. Kondisi seperti ini yang oleh Ainurrafiq disebut sebagai perubahan fungsi dan perubahan manajemen pesantren. Lihat Ainurrafiq, "Pesantren dan Pembaruan: Arah dan Implikasi" dalam Abuddin Nata (ed.), Sejarah Pertumbuhan dan Perkembangan Lembaga-lembaga Pendidikan Islam di Indonesia (Jakarta: Gramedia, 2001), 158.

33 Yang paling menonjol adalah pengembangan kurikulum yang menunjukkan dinamika yang terus menerus hingga saat ini baik yang ada di pondok induk, pondok unit maupun pondok cabang. Dalam sejarah panjangnya, kurikulum yang
} 
Selain menemukan berbagai buku karya ilmiah yang dihasilkan oleh santri, peneliti juga menemukan fakta-fakta lain yang mengindikasikan adanya proses akomodasi pondok pesantren ini terhadap perkembangan ilmu pengetahuan dan teknologi. Di antara fakta-fakta tersebut antara lain: pertama, penggunaan teropong dan kalkulator saintifik sebagai media pembelajaran ilmu falak, ${ }^{36}$ dan kedua, komputerisasi dan penggunaan internet dalam tata kelola manajemen pondok pesantren dan peningkatan komunikasi.

Dapat disimpulkan bahwa cepatnya perkembangan ilmu pengethuan dan teknologi pada akhirnya mempengaruhi dinamika tadisi salaf di Pondok Pesantren Lirboyo. Hal ini semakin memperkuat anggapan bahwa sebuah tradisi tidak pernah berada satu kondisi secara terus menerus karena dia akan bersentuhan dengan tradisi lain di luar dirinya. Ada ragam aspek tradisi yang mengalami pergesaran, sebagian atau seluruhnya, sekuat apapun pemilik tradisi tersebut mempertahankannya. Pergeseran semacam itu akan mengarah pada dua kemungkinan yaitu kesinambungan ataupun perubahan.

\section{Implikasi Continuity and Change Tradisi Salaf di Pesantren Lirboyo}

Mencermati berbagai faktor yang mendorong terjadinya dinamika kehidupan sosial dan tradisi yang ada di Pondok Pesantren Lirboyo, maka dapat dikatakan bahwa faktor internal lebih dominan jika dibandingkan dengan faktor eksternal. Konsekuensi dari keadaan

semula berisi pelajaran keagamaan, saat ini lebih menunjukkan adanya upaya pengintegrasian antara ilmu agama dengan ilmu umum.

${ }^{34}$ Diterimanya sistem madrasi dalam sistem pendidikan di Pesantren Lirboyo dapat dikategorikan sebagai proses akomodasi terhadap ilmu pengetahuan yang berupa manajemen organisasi.

35 Yang dimaksud dengan karya tulis ilmiah dalam konteks ini adalah karya ilmiah berbahasa Indonesia yang dihasilkan oleh para santri. Kebanyakan karya ilmiah berupa buku yang diterbitkan dan artikel yang kebanyakan dimuat di website pondok pesantren. Selain keterampilan menulis karya ilmiah, pondok pesantren ini juga mendirikan lembaga penerbitan Lajnah Ta'lif wa al-Nasyr (LTN) pada tahun 2002.

${ }^{36}$ Pada awalnya ilmu falak diajarkan dengan bantuan alat sederhana berupa alat yang terbuat dari kayu yang berbentuk seperempat lingkaran $\left(r u b u^{\circ}\right)$ yang bisa digunakan untuk menentukan arah kiblat. Sementara untuk menentukan awal bulan atau awal tahun (hisab) diajarkan dengan cara menghitung secara manual menggunakan rumus tertentu. 
tersebut, maka dinamika tradisi salaf yang ada di Pondok Pesantren Lirboyo lebih mengarah pada proses reproduksi daripada reformasi. Sebagaimana diketahui sebelumnya, proses reproduksi merupakan proses pengulangan, dan menghasilkan kembali segala hal yang diterima sebagai warisan budaya dari nenek moyang sebelumnya. Dalam proses ini, aspek yang berbentuk norma dan nilai sulit untuk berubah karena ada kecenderungan untuk dipertahankan. Dalam kondisi seperti itu maka perubahan hanya terjadi sebagian, terbatas ruang lingkupnya, tanpa menimbulkan akibat besar terhadap unsur lain dari sistem sosial Pondok Pesantren Lirboyo. Sistem sebagai keseluruhan tetap utuh, tak terjadi perubahan menyeluruh atas unsurunsurnya meski didalamnya terjadi perubahan sedikit demi sedikit. Dengan kata lain, dinamika yang ada di Pondok Pesantren Lirboyo hanya menyentuh perubahan di tingkat mikro.

Kemudian jika dihubungkan dengan ruang lingkup perubahan, faktor-faktor yang mempengaruhi gerak tradisi salaf di Pesantren Lirboyo menyentuh beberapa unsur tradisi dan dapat diidentifikasi dengan penjelasan sebagai berikut:

a. Ruang lingkup berupa perubahan komposisi dapat dilihat pada sistem sosial yang dibentuk oleh Kiai. Data penelitian ini menunjukkan adanya tumpang tindih dalam hierarki garis keturunan akibat perkawinan antar-saudara. Faktor yang menciptakan kondisi seperti itu adalah adanya pemikiran bahwa Pesantren Lirboyo adalah warisan dari leluhur sehingga harus dijaga bersama. Membentuk ikatan keluarga di antara sesama keturunan dari Kiai Abdul Karim bertujuan agar semua ikut bertanggung jawab atas keberlangsungan lembaga pendidikan peninggalan leluhur tersebut. ${ }^{37}$

b. Ruang lingkup berupa perubahan struktur dapat dilihat pada bangunan keilmuan di Pondok Pesantren Lirboyo dari yang semula hanya dibentuk dari ilmu keagamaan murni menuju perpaduan antara ilmu agama dan non-agama. ${ }^{38}$ Perubahan

\footnotetext{
${ }^{37}$ Kiai Ilham Nadhir, salah seorang alumni Pondok Pesantren Lirboyo yang paling senior, mengilustrasikan pernikahan antar-kerabat tersebut sebagai bareng-bareng ngopeni tinggalane mbahe (bersama-sama menjaga dan memelihara peninggalan orang tuanya). Kiai Ilham Nadhir, Wawancara, Kediri 16 Agustus 2016.

38 Dalam kasus ini, perubahan terjadi disebabkan oleh pertemuan antara faktor internal dan eksternal. Faktor eksternal berupa perkembangan sistem pendidikan umum yang kemudian berubah menjadi kebutuhan wali santri. Sementara faktor internal berupa kesediaan Kiai untuk memenuhi kebutuhan wali santri.
} 
struktur juga terjadi pada sistem sosial yang dibentuk oleh Kiai yaitu terjadinya kristalisasi kekuasaan pada sosok individu-individu yang tergabung dalam BPK P2L. ${ }^{39}$

c. Ruang lingkup berupa perubahan fungsi dapat dilihat pada bangunan keilmuan di Pondok Pesantren Lirboyo yaitu terjadinya diferensiasi fungsi pondok pesantren yang semula menyiapkan santri menjadi ahli agama (kader ulama) menjadi lembaga yang tidak hanya membekali santrinya dengan ilmu agama tetapi juga dengan ilmu non-agama. Selain itu, perubahan fungsi juga terjadi pada sistem sosial yang dibentuk oleh kiai yaitu adanya spesialisasi tugas dan pekerjaan antara kiai yang mengelola urusan internal pondok pesantren dengan yang mengelola urusan eksternal pesantren.

d. Ruang lingkup berupa perubahan batas dapat dilihat pada proses demokratisasi sistem melalui pemberian hak otonom bagi pondok unit dan pondok cabang. ${ }^{40}$

e. Ruang lingkup berupa perubahan hubungan antar subsistem dapat dilihat pada terjadinya pengendalian sistem pendidikan agama terhadap sistem pendidikan umum. ${ }^{41} \mathrm{Hal}$ ini disebabkan oleh faktor komitmen kuat untuk mempertahankan nilai-nilai tradisi salaf sebagai warisan yang harus dilestarikan, serta adanya konsensus untuk menjaga pondok induk tetap pada posisi semula sebagai lembaga pendidikan yang khusus mengajarkan ilmu

\footnotetext{
${ }^{39}$ Perubahan ini murni terjadi akibat faktor internal berupa gagasan cemerlang Kiai Mahrus Aly untuk mempertahankan keutuhan keluarga besar Kiai Abdul Karim dalam mengelola Pesantren Lirboyo.

${ }^{40}$ Keluarga kiai yang sering bersentuhan dengan tradisi luar seringkali membawa gagasan baru masuk ke dalam sistem kehidupan Pesantren Lirboyo sebagaimana yang terjadi pada kasus mendirikan sekolah formal. Agar gagasan tersebut tidak "mengganggu" kelangsungan tradisi, maka ditempuh jalur kompromi dengan cara mewadahi gagasan-gagasan dari luar tersebut pada pondok unit dan pondok cabang. Kemudian pondok-pondok tersebut diberi hak otonom untuk mengelola pendidikannya dengan catatan bahwa mereka harus mempertanggungjawabkannya kepada Badan Pembina Kesejahteraan Pondok Pesantren Lirboyo (BPK P2L) sebagai institusi yang memiliki kewenangan tertinggi.

${ }^{41}$ Contoh paling konkret dari kasus ini adalah apa yang terjadi pada pondok unit PP al-Mahrusiyah. Pondok unit ini mengelola begitu banyak lembaga pendidikan formal yang mengajarkan ilmu-ilmu umum. Akan tetapi menariknya, kenaikan siswa pada pendidikan formal ditentukan oleh hasil belajarnya di madrasah diniyah. Jika seorang siswa tidak naik tingkatan pada madrasah diniyah, maka secara otomatis siswa tersebut tidak bisa naik kelas/tingkat pada pendidikan formalnya. Kiai Reza Ahmad Zahid Imam, Wawancara, Kediri 23 Agustus 2017.
} 
agama. ${ }^{42}$ Selain itu juga terjadi dalam hal pergeseran kepengasuhan pondok pesantren mulai dari kepemimpinan tunggal, kepemimpinan dwitunggal, hingga kepemimpinan kolektif kolegial yang diwadahi oleh lembaga yang bernama BPK P2L.

f. Ruang lingkup berupa perubahan lingkungan dapat dilihat pada sistem pendidikan yang tidak lagi terpusat pada satu tempat (pondok induk) tetapi menyebar ke pondok unit yang berada di sekitar pondok induk hingga ke pondok cabang yang berada di luar daerah. Indikasi lain adalah diterimanya "orang luar" sebagai tenaga pendidik pada lembaga pendidikan formal yang berada di lingkungan Pesantren Lirboyo. Konsekuensi logis dari diterimanya sistem pendidikan umum menuntut Pondok Pesantren Lirboyo membuka diri bagi masuknya "orang luar" menjadi tenaga pengajar. ${ }^{43}$

Dengan mengamati dan mencermati arah perubahan yang terjadi pada tradisi salaf di Pesantren Lirboyo dapat pula disimpulkan bahwa dinamika yang terjadi pada tradisi salaf di pondok pesantren tersebut dapat digolongkan ke dalam jenis perubahan evolusioner. Perubahan evolusioner adalah perubahan yang terjadi secara sinambung dan teratur dengan arah tertentu, dalam proses adaptasi atau penyesuaian dengan suatu lingkungan tertentu. Diterimanya sistem pendidikan formal/umum dalam bentuk madrasah (MTs dan MA) dan sekolah (SD, SMP, SMA, dan SMK) dilandasi oleh pemikiran kiai dan para pengelola Pondok Pesantren Lirboyo yang ingin melayani keinginan orang tua santri agar anaknya selain memperoleh ilmu agama melalui pembelajaran di pesantren juga dapat memiliki ijazah formal yang bisa digunakan untuk memasuki lapangan kerja. Demikian pula yang terjadi ketika Kiai mengizinkan sistem komputerisasi pada administrasi pondok pesantren dan diperkenalkannya internet kepada komunitas pondok pesantren.

Dinamika sosial yang terjadi di Pesantren Lirboyo juga menunjukkan kecenderungan untuk berubah secara terus-menerus. Dengan dalih memperbaiki sistem pendidikannya, lembaga

\footnotetext{
${ }^{42}$ Kiai Dahlan Ridlwan, Wawancara, Kediri 27 Desember 2017.

${ }^{43}$ Pada bentuknya yang awal ketika pondok pesantren ini hanya mengajarkan ilmu agama, maka kebutuhan akan tenaga pendidik dipenuhi dengan mengangkat santri senior yang dianggap mampu untuk membantu Kiai dalam proses pembelajaran. Namun tidak demikian ketika pendidikan formal didirikan. Kebutuhan akan tenaga pengajar, terutama ilmu-ilmu umum, tidak bisa dipenuhi sendiri oleh Pesantren Lirboyo. Satu-satu cara ialah dengan merekrut tenaga dari luar pondok pesantren.
} 
pendidikan agama ini bergerak dari satu keadaan pada keadaan lainnya. Inilah yang disebut sebagai negentropi atau kecenderungan sistem pada struktur besar. Perubahan yang terjadi pada pondok pesantren ini, setidaknya hingga saat penelitian ini dilakukan, tidak menunjukkan tanda-tanda untuk berhenti pada suatu keadaan tertentu (entropi) di mana ada kecenderungan sistem berhenti bekerja. Oleh karena itu, penulis memprediksi bahwa penelitian tentang Pesantren Lirboyo akan menghasilkan kesimpulan yang berbeda-beda sesuai dengan kurun waktu dilakukannya penelitian.

\section{Penutup}

Dalam perspektif continuity and change, tradisi salaf di pondok pesantren tersebut mengalami apa yang penulis sebut sebagai "kontinuitas substansial" dan "perubahan parsial". Kontinuitas substansial dan perubahan parsial tersebut dapat dilihat pada unsurunsur tradisi salaf yang mengalami dinamisasi, antara lain: pertama, bangunan keilmuan secara substansial mengalami kontinuitas, yakni melestarikan dan tetap setia pada pengajaran ilmu agama yang bersumber pada kitab-kitab klasik. Secara parsial mengalami perubahan yang terjadi pada aspek metode pembelajaran, pengembangan kurikulum, dan diterimanya tenaga pengajar dari luar pondok pesantren; kedua, struktur sosial yang ada di Pesantren Lirboyo secara substansial berkesinambungan dengan menempatkan kiai sebagai patron yang memiliki kedudukan sosial sangat tinggi dan dihormati oleh para santri. Perubahan-perubahan parsial terjadi pada aspek pola kepengasuhan, pembagian tugas kepengasuhan, demokratisasi sistem melalui pemberian hak otonom bagi pondok unit dan pondok cabang, dan penyebaran santri serta lingkungan pendidikannya; ketiga, relasi Pesantren Lirboyo dengan tarekat tetap pada kondisi tidak mengikatkan diri pada salah satu tarekat mainstream dan setia pada tarekat yang diasuh oleh Kiai Abdul Karim sebagai pendiri yaitu tariqat al-ta'lim wa al-Ta'allum.

Adapun faktor-faktor yang mendorong terjadinya continuity and change pada tradisi salaf di dalam sistem pendidikan Pesantren Lirboyo secara garis besar dapat dibedakan menjadi dua bagian, yaitu: faktor internal yang menyebabkan terjadinya perubahan yang bersifat endogenus, dan faktor eksternal yang menyebabkan perubahan exogenous. Faktor internal yang mempengaruhi dinamika tradisi salaf dalam sistem pendidikan Pesantren Lirboyo di antaranya: pertama, sikap dan 
pemikiran kiai sebagai pelayan umat (khädim al-ummah). Kesetiaan kiai pada tradisi salaf harus berkompromi dengan pelayanan terhadap kebutuhan santri dalam mencapai tujuan pendidikannya; kedua, kondisi objektif santri yang heterogen dengan tradisi yang dibawa dari daerah asalnya masing-masing. Sementara faktor eksternal yang mempengaruhi dinamika tradisi salaf di dalam sistem pendidikan di Pondok Pesantren Lirboyo Kediri antara lain: pertama, perkembangan sistem pendidikan umum yang sebagian di antaranya diakomodir menjadi bagian integral dari sistem tradisi Pondok Pesantren Lirboyo; dan kedua, perkembangan ilmu pengetahuan dan teknologi (IPTEK) yang sulit untuk dihindari.

\section{Daftar Rujukan}

Ainurrafiq. "Pesantren dan Pembaruan: Arah dan Implikasi" dalam Abuddin Nata (ed.), Sejarah Pertumbuban dan Perkembangan Lembagalembaga Pendidikan Islam di Indonesia. Jakarta: Gramedia, 2001.

Anwar, Ali. Pembaharuan Pendidikan di Pesanten Lirboyo Kediri. Yogyakarta: Pustaka Pelajar, 2011.

Azra, Azyumardi. Pendidikan Islam: Tradisi dan Modernisasi Menuju Milenium Baru. Jakarta: Logos, 1999.

Azra, Azyumardi. Renaisans Islam Asia Tenggara: Sejarah Wacana dan Kekuasaan. Bandung: Remaja Rosdakarya, 1999.

Baso, Ahmad. Islam Nusantara: Ijtibad Jenius \& Ijma' Ulama Indonesia, Vol. 1. Tangerang Selatan: Pustaka Afid, 2017.

Baso, Ahmad. Pesantren Studies, Jilid 2a. Jakarta: Pustaka Afid, 2013.

Bruinessen, Martin van. NU, Tradisi, Relasi-relasi Kuasa: Pencarian Wacana Baru, terj. Farid Wajidi. Yogyakarta: LKiS, 2004.

Dhofier, Zamakhsyari. Tradisi Pesantren: Studi tentang Pandangan Hidup Kiai. Jakarta: LP3ES, 2011.

Geertz, Clifford. "The Javanese Kijaji: The Changng Role of Cultural Broker" Comparative Studies in Society and History, Vol. 2, No. 2, 1960.

Horikoshi. Kyai dan Perubahan Sosial. Jakarta: P3M, 1987.

Imam, Kiai Reza Ahmad Zahid. Wawancara. Kediri 23 Agustus 2017.

Karni, Asrori S. Etos Studi Kaum Santri: Wajah Baru Pendidikan Islam. Bandung: Mizan Media Utama, 2009.

Kartasapoetra, G. dan Hartini. Kamus Sosiologi dan Kependudukan. Jakarta: Bumi Aksara, 1992. 
Langgulung, Hasan. Pendidikan Islam Menghadapi Abad ke-21. Jakarta: Pustaka al-Husna, 1988), 75.

Madjid, Nurcholish. "Merumuskan Kembali Tujuan Pendidikan Pesantren", dalam M. Dawam Rahardjo (ed.), Pergulatan Dunia Pesantren, Membangun dari Bawah. Jakarta: P3M, 1985.

Mahrus, Kiai An'im Falahuddin. Wawancara. Kediri 18 Januari 2017.

Mahrus, Kiai Kafabihi. Wawancara. Kediri 25 Januari 2017.

Nadhir, Kiai Ilham. Wawancara. Kediri 16 Agustus 2016.

Nasir, Ridwan. Mencari Tipologi Format Pendidikan Ideal: Pondok Pesantren di Tengah Arus Perubahan. Yogyakarta: Pustaka Pelajar, 2010.

Penyusun, Tim. Pesanten Lirboyo: Sejarah, Peristiwa, Fenomena, dan Legenda. Kediri: BPK P2L bekerjasama dengan Lirboyo Press, 2015.

Ridlwan, Kiai Dahlan. Wawancara. Kediri 27 Desember 2017.

Saleh, Abdul Rachman. Pendidikan Agama dan Keagamaan: Visi, Misi, dan Aksi. Jakarta: Gemawindu Pancaperkasa, 2000.

Steenbrink, Karel A. Pesantren, Madrasah, Sekolah: Pendidikan Islam dalam Kurun Modern. Jakarta: LP3ES, 1994.

Wahid, Abdurrahman. "Benarkah Kyai Membawa Perubahan Sosial?: Sebuah Pengantar" dalam Hiroko Horikoshi, Kyai dan Perubahan Sosial. Jakarta: P3M, 1987.

Wahid, Abdurrahman. "Pesantren sebagai Subkultur" dalam M. Dawam Rahardjo, Pesantren dan Pembaharuan. Jakarta: LP3ES, 1985.

Wahid, Abdurrahman. Menggerakkan Tradisi: Esai-esai Pesantren. Yogyakarta: LKiS, 2010.

Zaini, KH.A. Habibullah. "Kata Pengantar" dalam Tim Penyusun, Ketetapan Badan Pembina Kesejahteraan Pondok Pesantren Lirboyo Masa Khidmah: 1437-1438 H./2016-2017 M. Kediri: t.tp., 2016.

Zuhri, Saefuddin. Guruku Orang-orang Pesantren. Bandung: PT. AlMa'arif, 1988. 